


ASIAN VALUES AND HUMAN RIGHTS

\section{A CONFUCIAN} COMMUNITARIAN PERSPECTIVE WM. THEODORE DE BARY
In this provocative book, one of our most learned scholars of China moves beyond the political shouting match surrounding human rights in China by contextualizing this debate from a Confucian and a historical perspective. "Asian Values" is a concept advanced by some authoritarian regimes to differentiate an Asian model of development, supposedly based on Confucianism, from a Western model identified with liberal democracy. Highlighting the philosophical development of Confucianism as well as the Chinese historical experience with community organization, constitutionalism, education, and women's rights, de Bary argues that while the Confucian sense of personhood differs in some respects from Western libertarian concepts of the individual, it is not incompatible with human rights.

"De Bary persuasively argues that elements of Confucianism have the potential to evolve into a democratic government. With his profound and broad knowledge of Confucianism, he vividly describes a variety of Confucian values and programs that could nurture a modern liberalism."

-Merle Goldman, Boston University

$\$ 27.95$ cloth

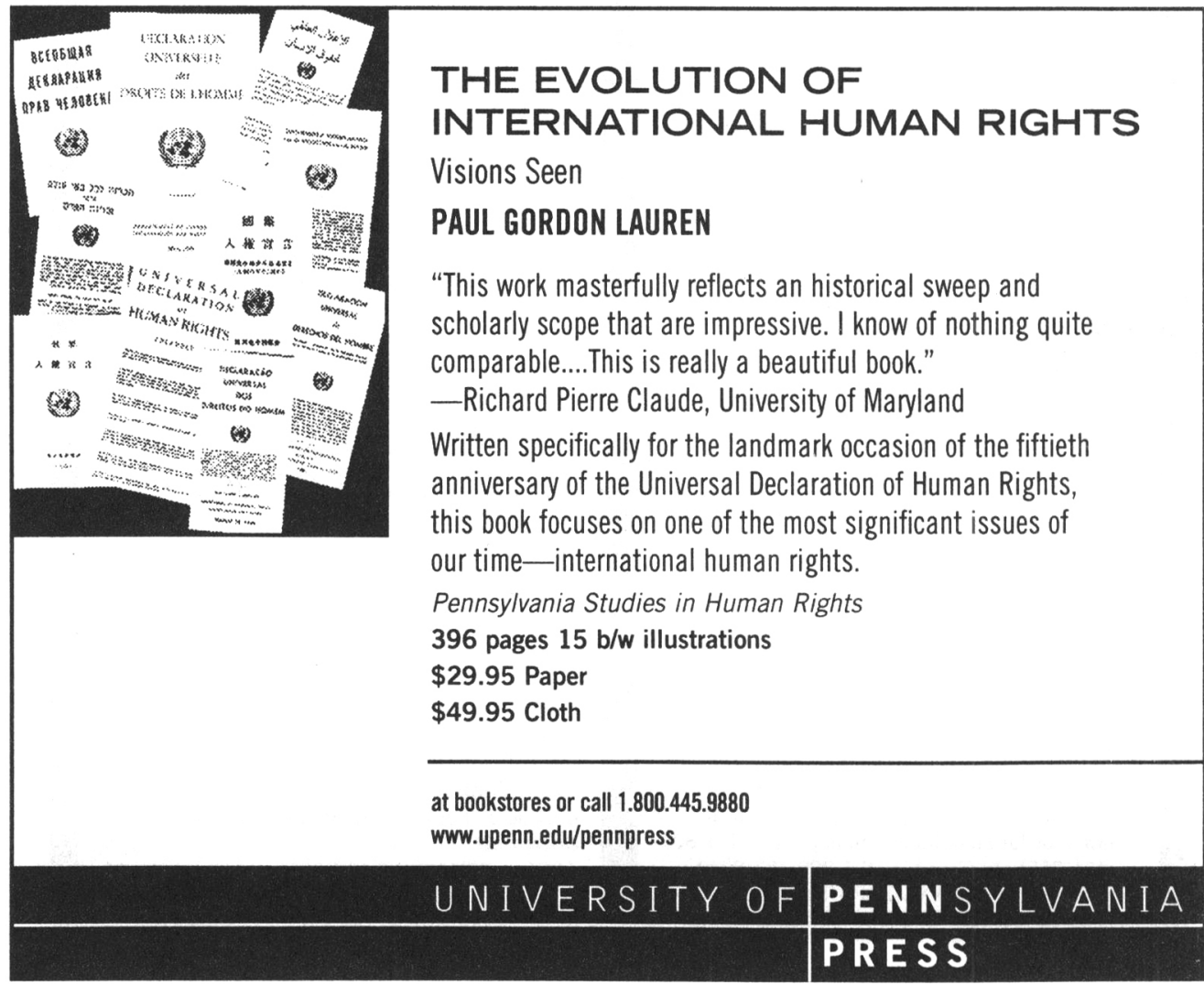




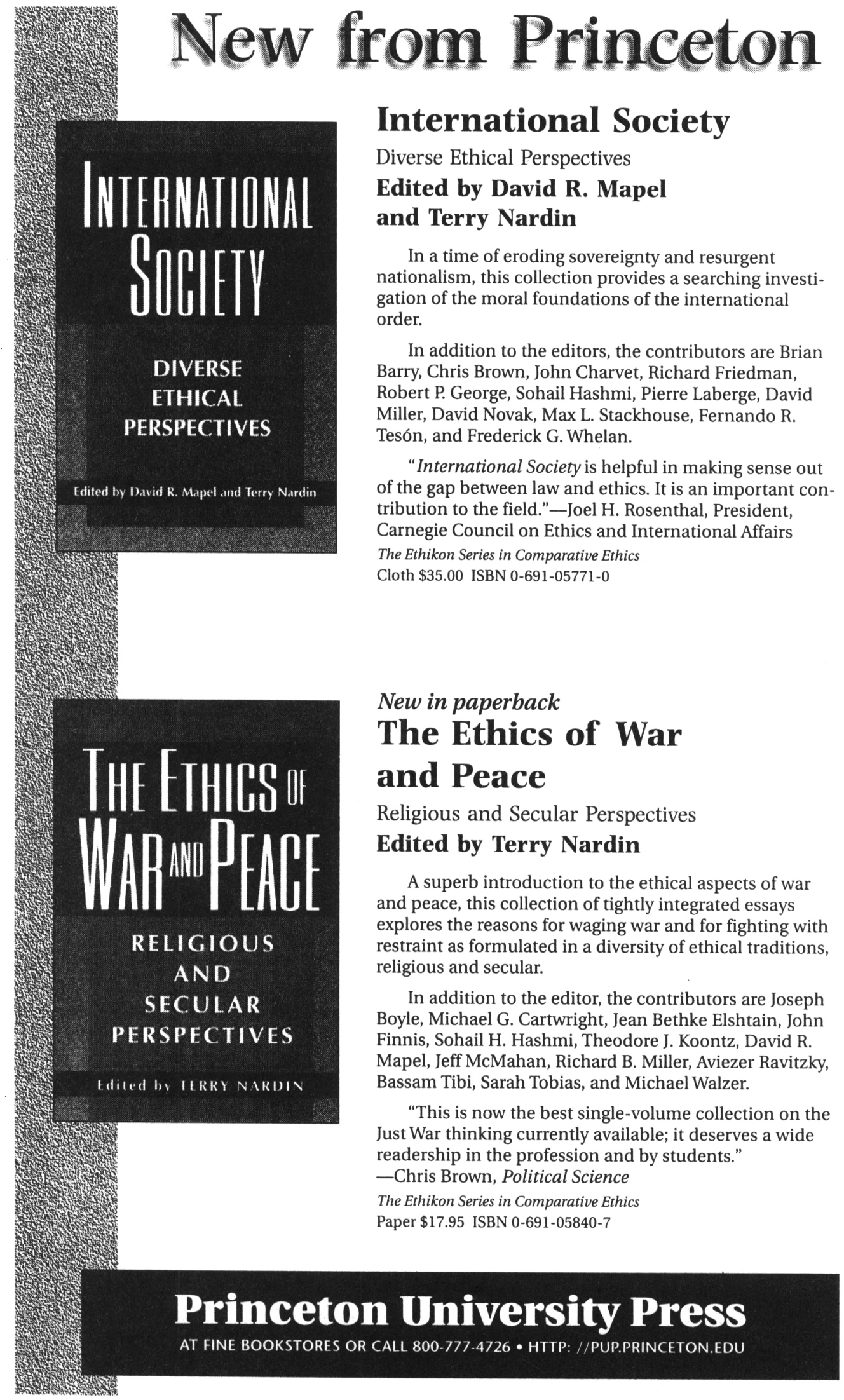




\section{Important International Law Titles from...}

\section{RESHAPING THE WORLD \\ TRADING SYSTEM}

A History of the Uruguay Round

by John Croome

The Uruguay Round, perhaps the most ambitious programme of worldwide negotiations ever attempted on any economic subject, lasted over seven years from 1986 to 1994. The success of the Uruguay Round has defined the shape of the world trading system for the next generation. The agreements reached have set in place a new World Trade Organization and new rules for trade and economic development worth hundreds of billions of dollars in the years ahead.

This book traces the history and evolution of the Uruguay Round. It seeks to explain, in an accessible and non-technical way, how the Uruguay Round came about, why it covered the subjects it did, what the participants sought, and the twists, turns, setbacks, and successes in each sector of the negotiation.

November 1998,360 pp., Hardbound, ISBN: 9041111263 , Price: $\$ 90.00$

\section{THE NEW CHEMICAL WEAPONS CONVENTION}

Implementation and Prospects

edited by Michael Bothe, Allan Rosas

The Chemical Weapons Convention constitutes an important achievement in disarmament law and also a step forward in general international law, as the Convention, in order to solve a serious security problem, establishes an unprecedented regime for controlling relevant state and private behaviour, administered by a newly-created international organization. Being both new and complex, there is a considerable need for interpretation and explanation.

This book is the result of a common research project of three teams directed by the three editors. It reviews the history of the negotiations and then presents a thorough analysis of the major theatres of the Convention: the organization, the verification regime, dispute settlement and reactions to non-compliance. More specific issues include confidentiality, application during armed conflicts, trade issues and national implementation.

February 1998,600 pp., Hardbound, ISBN: 9041110992 , Price: $\$ 189.00$

\section{PLANNING FOR INTERVENTION \\ International Cooperation in Conflict Management by Antonia Handler Chayes, Abram Chayes}

This important volume by two renowned scholars offers a radical and original strategy to change the way the problem of intervention into internal state conflicts is handled by the world community of nations. Planning for Intervention examines both the failures and successes of intervention by the international community into the internal conflicts that are plaguing the post cold war world. It examines the legal framework and the bureaucratic and political realities that govern intervention and helps to explain why performance has been so uneven.
The strategy offered by the authors operates within the parameters of legal and political limits to improve effectiveness by increasing international cooperation. Although radical and original in the context of international intervention, it has strong precedents in both industry and in actual conflict resolution.

This groundbreaking work is essential reading for all those in government agencies, international organizations, and policy making positions as well as scholars and practitioners concerned with issues of international conflict management and resolution.

March 1999, 200 pp., Hardbound, ISBN: $904110643 x$, Price $\$ 65.00$

\section{KLUWER LAW INTERNATIONAL}




\section{KLUWER LAW INTERNATIONAL}

REFLECTIONS ON THE UNIVERSAL DECLARATION OF HUMAN RIGHTS:

A Fiftieth Anniversary Anthology

edited by Barend van der Heijden, and Bahia Tahzib-Lie, on behalf of The Netherlands Ministry of Foreign Affairs

Launched on the occasion of the 50th anniversary of the Universal Declaration of Human Rights, this unmatched anthology includes inspirational essays by 50 prominent, varied members of the world community, moving poems reflecting a wide range of renowned voices, and full-colour illustrations of each article of the Universal Declaration.

Reflections on the Universal Declaration of Human Rights also includes a foreword by the Netherlands Minister for Foreign Affairs.
The importance and variety of the voices united in this work, the monumental occasion it marks, and the beauty and quality showcased on its pages make it an essential addition to the personal and professional libraries of anyone interested in human rights.

All royalties from Reflections on the Universal Declaration of Human Rights are being donated to the UN Voluntary Fund for Victims of Torture, and the UNFPA Trust Fund for the Elimination of Female Genital Mutilation.

October 1998, 350 pp., Hardbound, ISBN: 9041110461 , Price: $\$ 41.00$

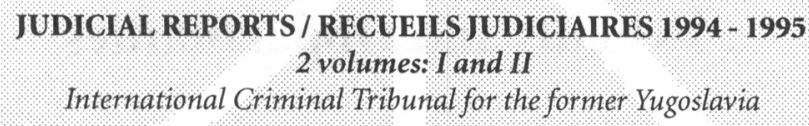

The Judicial Reports/ Recueils judici. aires of the International Criminal Tribunal for the former Yugoslavia (ICTY) comprise (in English and French) all public Indictments, as well as Decisions and Judgements issued in a given year. It gives lawyers, scholars, students, and the general public convenient access to the historic work of the ICTY, which was established pursuant to United Nations Security Council Resolution 827 in 1993 to try individuals accused of serious violations of international humanitarian law committed in the territory of the former Yugoslavia since 1991.

The Judicial Reports are organized chronologically by case. Within each case, one will find the text of Indictments, reviews of Indictments and where applicable, deferral requests. Thereafter the text of a public review of the Indictment pursuant to Rule 61 may follow. The publication also contains the texts of the Orders, Decisions and Judgements, as well as the separate and/or dissenting opinions that may accompany a given Trial Chamber or Appeals Chamber ruling.

The Judicial Reports will contribute to a greater knowledge of the judicial activities of the ICTY. Various annexes, such as a table of cases, a list of Indictments and Indictees, a table of Deferrals and of Rule 61 Procedures, as well as a table of references facilitate the use of these volumes.

\section{February 1999, 1238 pp., Hardbound, Set of 2 volumes, ISBN: 9041111654 , Price: $\$ 300.00$}

\section{Massachusetts Avenue • Cambridge, MA 02139 (617) 354-0140 - Fax: (617) 354-8595




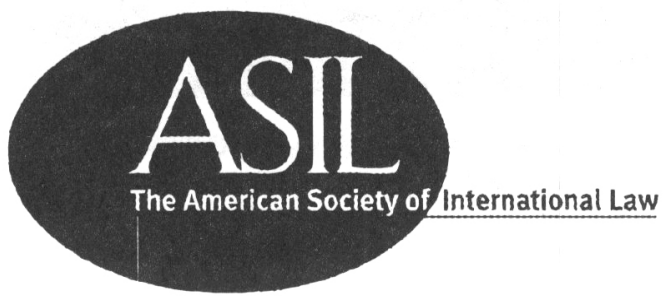

\section{Membership}

Through the years, the world has changed. Today, international law affects not only government relations, but economics, trade, the environment, communications, transportation, health and human rights. It has become vital, not only to influential policymakers, leading academics, government officials, and diplomats, but to attorneys, corporate decision makers, students and jurists located in towns large and small, across the country and throughout the world.

\section{Benefits and Opportunities}

The ASIL informs members through news and studies ... involves members through conferences, meetings, briefings and research groups . . . and helps members who have similar interests meet each other and work together through local networks and issue-specific groups.

With your membership in ASIL, you join the most active and respected international law society, dedicated to helping you more ably understand and apply the latest developments in international law, and forge those developments through direct action.

Membership includes a subscription to the premier quarterly, American Journal of International Law as well as the ASIL Newsletter. The ASIL extends its membership to individuals and groups whose activities or interests involve international law. Your membership is welcomed. Decide now to join the ASIL, your gateway to greater impact and effectiveness in today's world.

2223 Massachusetts Avenuc, NW • Washington, DC 20008-2864 Ph. 202-939-6000 • Fax 202-797-7133 • E-mail: services $₫$ asil org http://www.asil org 
Please Print

Name

Title/Position

Organization

\begin{tabular}{lll}
\hline City & State & Zip
\end{tabular}

Country

Phone Fax

\begin{tabular}{l}
\hline E-Mail \\
\hline Home Address \\
\hline City
\end{tabular}

Country

Phone Fax

E-Mail

Send Mail to: $\square$ Business $\square$ Home

Address Listing in Member Directory: $\square$ Business $\square$ Home $\square$ Do not List

$\square$ Check here if you do not wish to receive ASIL promotional materials by fax

Please select your membership category:

$\square$ Patron Member (one-time payment only)................................... \$7,500

口 Annual Patron............................................... \$ \$825

$\square$ Supporting Member.......................................... \$350

$\square$ Contributing Member..................................... \$225

$\square$ Regular Member ........................................... \$125

(Individuals, regardless of nationality or profession)

$\square \quad$ Intermediate Member .......................................... \$95

Individuals who are under 30 years of age. DOB

Individuals who are retired and 70 years of age or older

Special Member ........................................................ \$ $\$ 90$

Individuals whose gross annual income is under $\$ 35,000$ per year (please indicate income _ $\quad$; or, individuals who reside in developing countries and whose economic circumstances warrant Special Membership (please direct request to Executive Director with payment).

$\square$ Student Member

Requires verification of student status. Provide copy of student I.D. or verification of status from an administrator at your school. Year of graduation

$\square$ Organizational Member ....................................\$2,000 
Indicate which ASIL Interest Group(s) you wish to join: (check all that you wish to join)

\begin{tabular}{|c|c|c|}
\hline & Africa (43) & $\$ 5$ \\
\hline & Antarctic Law (31). & $\$ 5$ \\
\hline & Arms Control \& Non-Proliferation (46).. & $\$ 5$ \\
\hline & Dispute Resolution (32). & $\$ 7$ \\
\hline & Human Rights (36) & \\
\hline & Innovations in Teaching Internat & \\
\hline & Intellectual Property Law (51).. & \\
\hline & International Criminal Law (48).. & \\
\hline & International Economic Law (34) & $\$$ \\
\hline & International Environmental Law (35) & \\
\hline & International Legal Theory (50) & $\$ 12$ \\
\hline & International Organizations (37) & $\$ 10$ \\
\hline & International Space Law (40) & $\$ 10$ \\
\hline & Law in the Pacific Region (39) & $\$$ \\
\hline & ciety/Law of & \\
\hline & Private & \\
\hline & Rights of Indigenous Peoples (33) & \\
\hline & Status of Minorities and Other Communities (47 & \\
\hline & UN Decade of International Law (45) & 810 \\
\hline & Wildlife Law (42) & \\
\hline & Women in International Law (41 & \\
\hline & oung Members (49) & \\
\hline
\end{tabular}

\section{Calculate your total dues amount below:}

ASIL Annual Dues..............................\$

ASIL Interest Group(s)........................\$

International Legal Materials-\$95 ..............\$ (optional: offered to members at $50 \%$ off; Outside U.S.-\$155)

TOTAL $\$$

\section{Choose your method of payment:}

$\square$ Visa $\square$ MasterCard $\square$ American Express

Name

Card Number $\quad$ Exp. Date

Signature

C Check payable to ASIL (check must be drawn on a U.S. bank in U.S. funds)

Return membership application with payment to: ASIL PO Box 0164 Washington, DC 20055-0164 USA Or fax to 202-797-7133 


\section{New Internet Service! Oceana Online $\mathrm{T}^{\mathrm{TM}}$ \\ www.oceanalaw.com}

\section{New Products on Oceana Online!}

- TIARA U.S. Treaties Researcher ${ }^{\mathrm{TM}}$

- TIARA U.S. Treaties Index ${ }^{\mathrm{TM}}$

Oceana Online's TIARA U.S. Treaties Researcher ${ }^{\mathrm{TM}}$ and the TIARA U.S. Treaties Index ${ }^{\mathrm{TM}}$ provide full text and index listings of over 10,000 bi-lateral and multilateral treaties signed by the U.S. Using the powerful NetAnswer ${ }^{\mathrm{TM}}$ search engine, you'll get fast accurate answers to your search queries. Updated monthly, these are the most current sources for U.S. treaties information - even more timely than the official government publications!

\section{New Print Product!}

- Transnational Litigation: A Basic Primer Richard Kreindler, Jones, Day, Reavis \& Pogue Monograph, July 1998

- Trademark Practice \& Forms Karla Shippey, Hilborne, Hawkin \& Co. Looseleaf, June 1998

- Cybercrime \& Security A. Brill, The Kroll-O'Gara Company

R. Munro \& F. Baldwin, University of Florida Looseleaf, September 1998

- International Public Procurement Law Dennis Campbell, Centre for International Legal Studies Looseleaf, August 1998

- Annotated Guide to 1998 ICC Arbitration Rules with Commentary W.L. Craig, Coudert Fréres W. Park, Boston University, J. Paulsson, Freshfields Monograph, February 1998

- International Execution Against Judgement Debtors

Dennis Campbell, Centre for International Legal Studies Looseleaf, September 1998

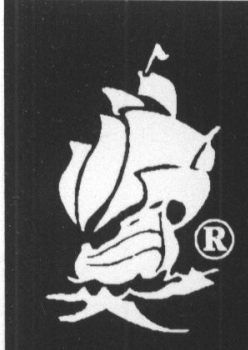

Oceana Publications, Inc. 75 Main Street

Dobbs Ferry, NY 10522-1601 USA

In the USA: 800-831-0758

Outside the USA: 914-693-8100

Fax: 914-693-0402

E-Mail: orders@oceanalaw.com 
THE AMERICAN JOURNAL OF I N TER N A T I O A L L A W

IS NOW AVAILABLE IN JSTOR!

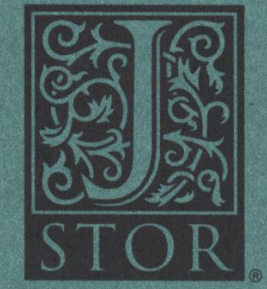

JSTOR, a not-for-profit organization, is an exciting new endeavor dedicated to helping the scholarly community take advantage of electronic technologies.

The JSTOR database consists of the complete backfiles of a number of scholarly journals and is available to researchers through libraries.

The American Journal of International Law is available in full text, fully searchable, from 1907-1994. JSTOR also includes 50 other renowned scholarly journals in political science, economics, history, and 10 other disciplines.

Information regarding JSTOR is available at http://www.jstor.org

as is a demonstration version of the database.

188 Madison Avenue, New York, NY 10016

TEL $212592.7345 \quad$ FAX 212592.7355 